trong nghiên cứu của chúng tôi cũng tương tự kết quả nghiên cứu của Lê Thị Thu Hiền (2017): xơ hóa gan F2 $(24,1 \%)$ và $F 3(25,3 \%)$ chiếm tỷ lệ cao nhất, xơ hóa gan $\mathrm{F} 4$ chiếm tỷ lệ thấp nhất (14,5\%) [1]; của Lê Quốc Tuấn (2019): BN giai đoạn viêm gan do rượu chiếm tỷ lệ là $87,4 \%$. Giai đoạn xơ hóa theo Metavir: giai đoạn F2 và $\mathrm{F} 3$ chiếm tỷ lệ lần lượt là $26,3 \%$ và $25,3 \%$; xơ hóa gan thực sự (F4) là 12,6\%. Mức độ xơ hóa gan đáng kể ( $\geq F 2$ ) chiếm tỷ lệ là $62,1 \%$ [2].

Nghiên cứu của Vũ Thị Thu Trang (2019) ở bệnh nhân GTHM cho thây loại xơ hóa hay gặp là xơ hóa quanh tế bào $(95,1 \%)$, xơ hóa quanh mao mạch nan hoa $(92,1 \%)$, xơ hóa khoảng cửa và quanh khoảng cửa $(80,4 \%)$. Tỷ lệ vách xơ là $22,5 \%$, cầu xơ là $14,7 \%$ và xơ gan là $4,9 \%$. Không có sự khác biệt về tỷ lệ xơ hóa quanh mao mạch nan hoa và quanh tế bào giữa hai nhóm GTHM do rượu và không do rượu. Tuy nhiên, tỷ lệ xơ hóa khoảng cửa và quanh khoảng cửa ở nhóm GTHM do rượu $(94,1 \%)$ cao hơn nhóm GTHM không do rượu $(62,8 \%)$, sự khác biệt có ý nghĩa thống kê với $p<0,001$ [3].

Như vậy, xơ hóa gan do rượu, xuất hiện đầu tiên vùng 3 và là minh chứng rằng $\mathrm{BN}$ uống nhiều rượu. Những $B N$ có xơ hóa gan đáng kể ( $\geq$ F2) cần được điều trị ngay, để tránh tiến triển thành xơ hóa gan nặng. Đối với $B N$ có xơ hóa gan nặng ( $\geq F 3)$, cần theo dõi để phát hiện biến chứng ung thư gan, giãn võ̃ tĩnh mạch thực quản.

\section{KẾT LUẬN}

- 100\% bệnh nhân mắc bênh gan do rượu có gan thoái hóa mỡ. Phần lớn là thoái hóa mở giọt nhỏ $(71,7 \%)$, mức độ nhe $(93,3 \%)$ và ở vùng 1 (90,0\%). Một số tổn thương khác hay gặp là thoái hóa hạt $(100 \%)$, thể Mallory $(65,0 \%)$, nhiễm sắc tố $(28,3 \%)$ và biến đổi ưa toan tế bào gan $(15,0 \%)$.

- Đánh giá giai đoạn xơ hóa gan theo phân loại Metavir thấy không xơ hóa gan (F0) là $6,7 \%$; xơ hóa nhe (F1) là $50,0 \%$; xơ hóa gan vừa (F2) là $11,7 \%$; xơ hóa gan nặng (F3) là $15,0 \%$ và xơ gan thực sự (F4) là $16,7 \%$.

\section{TÀI LIẸU THAM KHẢO}

1. Lê Thi Thu Hiền (2017), Nghiên cứu một số đặc điểm lầm sàng, cận lâm sàng và chỉ số chống oxy hóa trong máu ở bệnh nhân mắc bệnh gan do rượu, Luận án Tiễn sĩ y học, Đại học YD Thái Nguyên.

2. Lề Quốc Tuấn (2019), Nghiên cứu đă̆c điểm lâm sàng, cận lâm sàng và nồng đố một số cytokin huyết tương trên bệnh nhân mắc bểnh gan mạn do rượu, Luận án Tiên sĩ y học, Đại học YD Thái Nguyên.

3. Vũ Thị Thu Trang (2019), Nghiên cứu đăcc điểm lâm sàng, một số xét nghiệm, siêu âm và mồ bệnh hoc bệnh gan nhiếm mỡ, Luận án Tiến sĩ y học, Viện NCKHYDLS 108

4. Altamirano J., Miquel R., Katoonizadeh A. et al. (2014), "A histologic scoring system for prognosis of patients with alcoholic hepatitis", Gastroenterology, 146: 1231-1239.

5. Celli R., Zhang X. (2014), "Pathology of Alcoholic Liver Disease", Journal of Clinical and Translational Hepatology, vol. 2, 103-109.

6. Dubois M., Sciarra A., Trépo E. Et al. (2020), "Histologic parameter score does not predict shortterm survival in severe alcoholic hepatitis", United European Gastroenterol J., 8(9):1003-1012.

7. Ntandja Wandji L. C., Gnemmi V. et al. (2020), "Combined alcoholic and non-alcoholic steatohepatitis", JHEP Rep., 2(3): 100- 101.

8. Sakhuja P. et al (2014), "Pathology of alcoholic liver disease, can it be differentiated from nonalcoholic steatohepatitis? World J Gastroenterol., 20 (44): 16474-16479.

\title{
ĐẶC ĐIỂM MộT Số CHỈ Số HUYẾT HỌC VÀ ĐÔNG MÁU Ở BÊ̂NH GAN DO RƯợU
}

\author{
Seng Someth*, Trần Việt Tú*, Nguyễn Tùng Linh*
}

\section{TÓM TẮT}

Muc tiêu: Xác định đặc điểm và mối liên quan một số chỉ số huyết học và đông máu với mô bệnh hợ ở bênh gan do rượu. Đối tượng và phướng pháp: Gồm 60 bệnh nhân mắc bệnh gan do rượu điều

\footnotetext{
*Hoc viên Quân y

Chịu trách nhiệm chính: Seng Someth Email: nguyenvankhoi1980@gmail.com Ngày nhận bài: $1 / 7 / 2021$

Ngày phản biên khoa học: 1/8/2021

Ngày duyệt bài: 25/8/2021
}

trị nội trú tại Bênh viện Quân y 103, từ tháng 01/2015 đến $7 / 2017$. Các chỉ số nghiên cứu là số lượng hồng cầu, hàm lượng hemoglobin, số lượng bạch câu, số lượng tiểu cầu, tỷ lệ Prothrombin, thời gian APTT, nồng độ Fibrinogen và chỉ số INR. Kết quả và kết luân: $45,0 \%$ số bệnh nhân mắc bênh gan do rươu giảm số lượng hồng câu <4,2 T/l; 16,7\% bệnh nhẩn giảm nồng độ hemoglobin $<120 \mathrm{~g} / \mathrm{l}$ và $35,0 \%$ số bệnh nhân giảm số lượng tiểu cầu $<140 \mathrm{G} / \mathrm{l}$. Nồng độ $\mathrm{Hb}$ và số lượng tiểu cầu tương quan nghịch với giai đoạn xơ hóa gan trên mô bênh hoc $(r=-0,25$ và $r=-0,28$; $\mathrm{p}<0,05)$. Có $6,7 \%$ bệnh nhân giảm tỷ lệ Prothrombin $<70 \%$; có 3,3\% bệnh nhân tăng chỉ số INR >1,3. Có $13,3 \%$ bệnh nhân giảm nồng độ Fibrinogen <2 $\mathrm{g} / \mathrm{l}$ và 
$1,7 \%$ bệnh nhân có thời gian APTT kéo dài > 40 giây. Tỷ lệ Prothrombin (\%) tương quan nghịch với giai đoan xơ hóa gan $(r=-0,42 ; p<0,001)$, chỉ số INR tưởng quan thuận với giai đoạn xơ hóa gan trên mô bênh hoc $(r=0,37 ; p<0,01)$.

Tư khóa: Bệnh gan do rượu, huyết học, đông máu

\section{SUMMARY}

CHARACTERISTICS OF SOME HEMATOLOGICAL AND COAGULATION INDICATORS IN ALCOHOLIC LIVER DISEASE

Objectives: To determine the characteristics and relationship of some hematological and coagulation indices with histopathology in alcoholic liver disease. Subjects and methods: 60 patients with alcoholic liver disease were inpatient at 103 Military Hospital, from January 2015 to July 2017. The research indicators are red blood cell count, hemoglobin content, white blood cell count, platelet count, Prothrombin (\%), activated partial thromboplastin time (APTT), fibrinogen concentration and International normalized ratio (INR). Results and conclusion: $45.0 \%$ of patients with alcoholic liver disease reduced red blood cell count $<4.2 \mathrm{~T} / \mathrm{l} ; 16.7 \%$ of patients decreased hemoglobin concentration $<120$ $\mathrm{g} / \mathrm{l}$ and $35.0 \%$ of patients decreased platelet count $<140 \mathrm{G} / \mathrm{l}$. Hb concentration and platelet count were inversely correlated with the stage of liver fibrosis on histopathology $(r=-0.25$ and $r=-0.28 ; p<0.05)$. There were $6.7 \%$ patients reduced Prothrombin rate $<70 \%$; $3.3 \%$ of patients increased INR $>1.3$. There were $13.3 \%$ patients decreased Fibrinogen concentration $<2 \mathrm{~g} / \mathrm{l}$ and $1.7 \%$ patients had APTT duration $>40$ seconds. Prothrombin (\%) is negatively correlated with liver fibrosis stage $(r=-0.42 ; p<0.001)$, INR is positively correlated with liver fibrosis stage on histopathology $(r=0.37 ; p<0.01)$.

Keywords: Alcoholic liver disease, hematology, blood coagulation

\section{I. ĐĂT VẤN ĐỀ}

Ở bệnh nhân (BN) mắc bệnh gan do rượu (BGDR) thường có thiếu máu nhưng chỉ thiếu máu mức độ nhẹ. Nguyên nhân thiếu máu là do chảy máu do vỡ tĩnh mạch thực quản, thiếu acid folic và vitamin B12 (do thiếu hụt dinh dưỡng người nghiện rượu, cường lách, ức chế trực tiếp của ethanol lên tủy xương) Chỉ số MCV thường lớn hơn $95 \mathrm{fl}$, có thể do tác động trực tiếp của rượu lên tủy xương, lên tế bào gốc tạo máu [1], [3], [7]. Huang và Cs (2017) thấy MCV có liên quan với mức độ bênh, MCV ở nhóm VGDR mức độ năng là $103,3 \pm 12,5 \mathrm{fl}$, xơ gan do rướu là $94,2 \pm 1,38 \mathrm{fl}, \mathrm{VGDR}$ mức độ nhe là $91,8 \pm 7,8 \mathrm{fl}$ và GNM do rượu là $91,05 \pm 6 \mathrm{fl}$ [7].

\section{KẾT QUẢ NGHIÊN CỨU}

Bảng 1. Một số chỉ số huyết hơc ở bênh nhân mắc bênh gan do rươuu.

\begin{tabular}{|c|c|c|c|}
\hline \multicolumn{2}{|c|}{ Chỉ số } & Số BN $(\mathbf{n}=\mathbf{6 0})$ & Tỷ lệ (\%) \\
\hline Số lượng & Giảm $<4,2 \mathrm{~T} / \mathrm{I}$ & 27 & 45,0 \\
\hline
\end{tabular}

Giảm số lượng và chất lượng tiểu cầu thường gặp những $B N$ có bệnh gan mạn tính và chiếm khoảng $76 \%$ số BN xơ gan. Mức độ giảm tiểu cầu là một yếu tố tiên lượng nặng, đặc biệt nếu giảm tiểu cầu $<50 \mathrm{G} / \mathrm{l}$. Cơ chế giảm tiểu cầu bệnh gan do giảm sản xuất tiểu cầu trong tủy xương, cường lách, giảm sản xuất thrombopoietin và yếu tố tự miễn. Trong BGDR, do rượu ức chế tủy xương giảm sản xuất tiểu cầu, rượu còn tác dụng trực tiếp trên lipid tiểu cầu, hệ thống truyền tin thứ hai. Gan đóng vai trò trung tâm trong việc duy trì quá trình đông cầm máu. Gan là nơi tổng hợp phần lớn các protein cần thiết cho việc điều hòa đông máu và tiêu sợi huyết. Do đó, suy giảm chức năng tế bào gan có thể gây rối loạn quá trình đông cầm máu, $\mathrm{BN}$ có nguy cơ bị chảy máu hoặc hình thành huyết khối [3], [6].

Nghiên cứu được tiến hành nhằm: Xác định đặc điểm và mối liên quan môt số chỉ số huyết học và đông máu với mô bệnh học ở bệnh gan do rươu.

\section{II. ĐỐI TƯỢNG VÀ PHƯƠNG PHÁP NGHIÊN CỨU}

2.1. Đối tượng nghiên cứu. Gồm $60 \mathrm{BN}$ được chẩn đoán BGDR điều trị nội trú tại Khoa Nội tiêu hóa Bệnh viện Quân y 103, từ tháng 01/2015 đến 7/2017.

\subsection{Phương pháp nghiên cứu}

* Thiết kế nghiên cứu:

Nghiên cứu mô tả cắt ngang, có phân tích.

* Các chỉ số nghiên cứu:

- Phân tích một số chỉ số huyết học (số lượng hồng cầu: SLHC, hàm lượng hemoglobin, số lượng bạch cầu: SLBC, số lượng tiểu cầu: SLTC...) bằng máy Cell-Dyn 1700 (Mỹ) tại Khoa Huyết học - Bệnh viện Quân y 103.

- Phẩn tích một số chỉ số đông máu (tỷ lệ Prothrombin, thời gian APTT, nồng độ Fibrinogen và chỉ số INR) bằng máy CA 150 (hãng SysmexNhật Bản) tại Khoa Huyết học - Bệnh viện Quân y 103.

- Đặc điểm mô bệnh học: Phân chia giai đoạn xơ hóa gan theo Metavir: không xơ hóa (F0), xơ hóa gan nhẹ (F1), xơ hóa gan đáng kể (F2), xơ hóa gan nặng (F3) và xơ gan thực sự (F4).

- Các số liệu nghiên cứu được xứ lý theo phương pháp thống kê y sinh học theo chương trình SPSS 22.0. 
VIETNAM MEDICAL JOURNAL N01 - SEPTEMBER - 2021

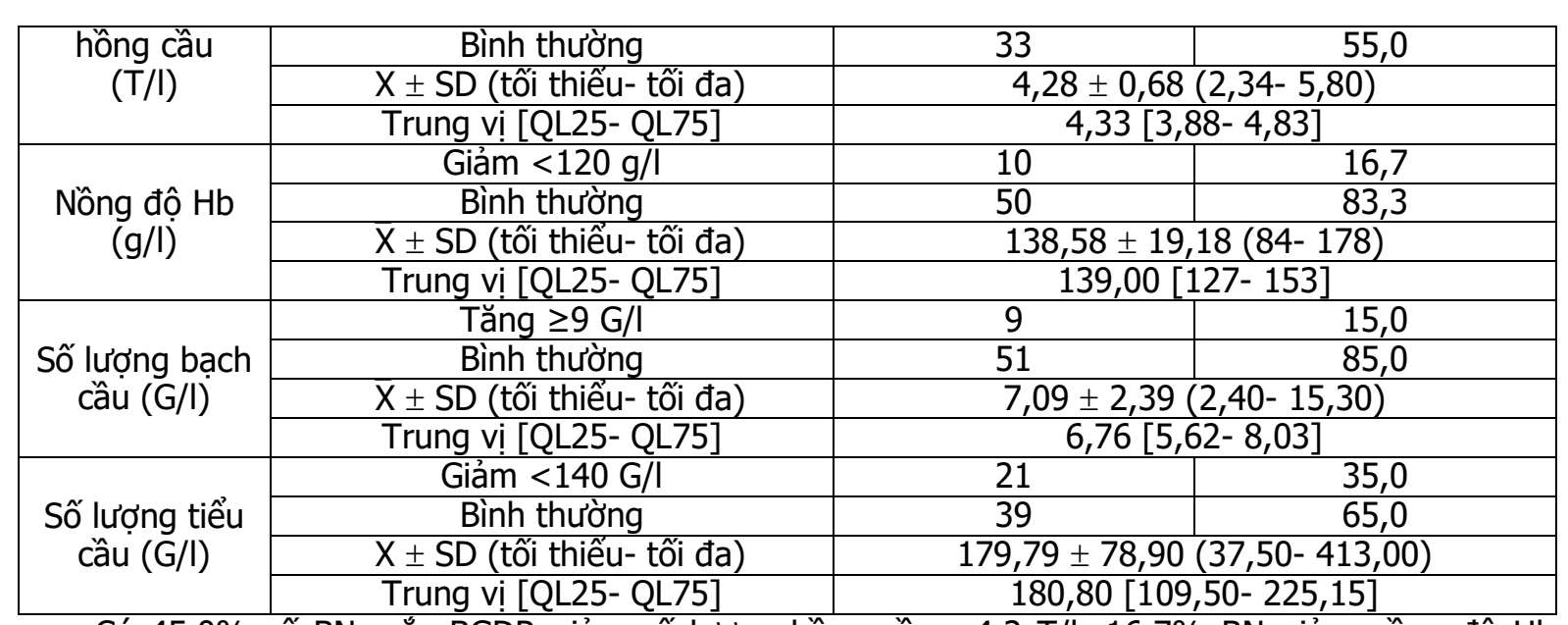

- Có 45,0\% số BN mắc BGDR giảm số lượng hồng cầu <4,2 T/l; $16,7 \% \mathrm{BN}$ giảm nồng độ $\mathrm{Hb}$ $<120 \mathrm{~g} / \mathrm{l}$ và $35,0 \%$ số $\mathrm{BN}$ giảm SLTC $<140 \mathrm{G} / \mathrm{l}$.

- SLBC trung bình là 7,09 $\pm 2,39(2,40-15,30) \mathrm{G} / \mathrm{l} ; 15,0 \%$ BN tăng SLBC $\geq 9 \mathrm{G} / \mathrm{l}$.

Bảng 2. Một số chỉ số đông máu ở bệnh nhân mắc bệnh gan do rượu.

\begin{tabular}{|c|c|c|c|}
\hline \multicolumn{2}{|c|}{ Chỉ số } & Số BN $(n=60)$ & Tỷ lê (\%) \\
\hline \multirow{4}{*}{$\begin{array}{c}\text { Tỷ lệ } \\
\text { Prothrombin } \\
(\%)\end{array}$} & Giảm $<70 \%$ & 4 & 6,7 \\
\hline & Bình thường & 56 & 93,3 \\
\hline & $\bar{X} \pm \mathrm{SD}$ (tối thiếu- tối đa) & \multirow{2}{*}{\multicolumn{2}{|c|}{$\frac{105,58 \pm 23,30(54,00-164,95)}{109,00[89-123]}$}} \\
\hline & Trung vị [QL25- QL75] & & \\
\hline \multirow{4}{*}{ Chỉ số INR } & Tăng $>1,3$ & 2 & 3,3 \\
\hline & Bình thường & 58 & 96,7 \\
\hline & $\mathrm{X} \pm \mathrm{SD}$ (tối thiếu- tối đa) & \multicolumn{2}{|c|}{$1,00 \pm 0,16(0,45-1,53)$} \\
\hline & Trung vị [QL25- QL75] & \multicolumn{2}{|c|}{$0,97[0,91-1,08]$} \\
\hline \multirow{4}{*}{$\begin{array}{l}\text { Nồng độ } \\
\text { Fibrinogen }\end{array}$} & Giảm $<2 \mathrm{~g} / \mathrm{l}$ & 8 & 13,3 \\
\hline & Bình thường & 52 & 86,7 \\
\hline & $\mathrm{X} \pm \mathrm{SD}$ (tối thiếu- tối đa) & \multicolumn{2}{|c|}{$3,43 \pm 1,32(1,43-7,32)$} \\
\hline & Trung vị [QL25- QL75] & \multicolumn{2}{|c|}{$3,28[2,63-4,05]$} \\
\hline \multirow{4}{*}{ Thời gian APTT } & Tăng $>40$ giây & 1 & 1,7 \\
\hline & Bình thường & 59 & 98,3 \\
\hline & $\mathrm{X} \pm \mathrm{SD}$ (tối thiếu- tối đa) & \multirow{2}{*}{\multicolumn{2}{|c|}{$\frac{28,28 \pm 4,57(14,40-40,30)}{27,75[25,72-30,22]}$}} \\
\hline & Trung vị [QL25- QL75] & & \\
\hline
\end{tabular}

Có 6,7\% BN giảm tỷ lệ Prothrombin <70\%; có 3,3\% BN tăng chỉ số INR >1,3. Có 13,3\% BN giảm nồng độ Fibrinogen $<2 \mathrm{~g} / \mathrm{l}$ và $1,7 \% \mathrm{BN}$ thời gian $\mathrm{APTT}$ kéo dài $>40$ giây.

Bảng 3. Liên quan một số chi số huyết học và mô bệnh hoc ở BN mắc BGDR.

\begin{tabular}{|c|c|c|c|c|}
\hline \multirow{2}{*}{$\begin{array}{l}\text { Giai đoạn } \\
\text { xơ hóa }\end{array}$} & \multicolumn{4}{|c|}{ Chỉ số huyết học $(X \pm S D)$} \\
\hline & SLHC (T/I) & $\mathrm{Hb}(\mathrm{g} / \mathrm{I})$ & $\operatorname{SLBC}(G / I)$ & SLTC (G/I) \\
\hline $\mathrm{FO}(\mathrm{n}=4)$ & $4,56 \pm 0,70$ & $149,00 \pm 12,30$ & $7,51 \pm 2,26$ & $194,00 \pm 23,90$ \\
\hline $\mathrm{F} 1(\mathrm{n}=30)$ & $4,40 \pm 0,64$ & $143,40 \pm 19,63$ & $6,57 \pm 1,54$ & $187,14 \pm 69,40$ \\
\hline$F 2(n=7)$ & $4,15 \pm 1,00$ & $132,14 \pm 23,27$ & $8,24 \pm 4,52$ & $256,17 \pm 100,82$ \\
\hline F3 $(n=9)$ & $3,83 \pm 0,64$ & $122,33 \pm 15,44$ & $7,72 \pm 3,16$ & $145,72 \pm 70,75$ \\
\hline $\mathrm{F} 4(\mathrm{n}=10)$ & $4,27 \pm 0,52$ & $139,10 \pm 11,15$ & $7,10 \pm 1,81$ & $129,26 \pm 71,20$ \\
\hline Tương quan & $\begin{array}{c}r=-0,19 \\
p>0,05\end{array}$ & $r=-0,25 ; p<0,05$ & $\begin{array}{c}r=0,10 ; \\
p>0,05\end{array}$ & $\begin{array}{c}r=-0,28 \\
p<0,05\end{array}$ \\
\hline
\end{tabular}

SLHC tương quan thuận với giai đoạn xơ hóa gan trên mô bênh hoc, nhưng sự khác biêt không có ý nghĩa thống kê $(p>0,05)$. Nồng độ Hb và SLTC tương quan nghịch với giai đoạn xơ hóa gan trên mô bệnh học, với hệ số tương quan Pearson $(r=-0,25$ và $r=-0,28)$, sự khác biệt có ý nghĩa thống kê với $p<0,05$.

Bảng 4. Liên quan một số chỉ số đông máu và mô bệnh học ở BN mắc BGDR. 


\begin{tabular}{|c|c|c|c|c|}
\hline \multirow{2}{*}{$\begin{array}{c}\text { Giai đoạn xơ } \\
\text { hóa trên mô } \\
\text { bênh hoc }\end{array}$} & \multicolumn{4}{|c|}{ Chỉ số đông máu ( $X \pm S D)$} \\
\hline & $\begin{array}{c}\text { Prothrombin } \\
(\%)\end{array}$ & $\begin{array}{c}\text { Chỉ số } \\
\text { INR }\end{array}$ & Fibrinogen ( $g / I)$ & $\begin{array}{c}\text { APTT } \\
\text { (giây) }\end{array}$ \\
\hline FO $(n=4)$ & $115,33 \pm 4,68$ & $0,93 \pm 0,02$ & $4,01 \pm 2,07$ & $26,87 \pm 2,24$ \\
\hline$F 1(n=30)$ & $113,61 \pm 23,09$ & $0,96 \pm 0,17$ & $3,49 \pm 1,24$ & $28,19 \pm 4,59$ \\
\hline $\mathrm{F} 2(\mathrm{n}=7)$ & $102,42 \pm 16,51$ & $0,99 \pm 0,09$ & $3,57 \pm 1,89$ & $26,41 \pm 4,46$ \\
\hline F3 $(n=9)$ & $94,04 \pm 19,46$ & $1,05 \pm 0,12$ & $3,13 \pm 1,09$ & $28,22 \pm 4,97$ \\
\hline $\mathrm{F} 4(\mathrm{n}=10)$ & $90,15 \pm 25,52$ & $1,12 \pm 0,21$ & $3,20 \pm 1,08$ & $30,51 \pm 4,78$ \\
\hline $\begin{array}{l}\text { Tương quan } \\
(r ; p)\end{array}$ & $\begin{array}{l}r=-0,42 \\
p<0,001\end{array}$ & $\begin{array}{l}r=0,37 \\
p<0,01\end{array}$ & $\begin{array}{c}r=-0,14 \\
p>0,05\end{array}$ & $\begin{array}{l}r=0,17 \\
p>0,05\end{array}$ \\
\hline
\end{tabular}

Tỷ lệ Prothrombin (\%) tương quan nghịch với giai đoạn xơ hóa gan trên mô bệnh học với hệ số tương quan Pearson $r=-0,42(p<0,001)$. Chỉ số INR tương quan thuận với giai đoạn xơ hóa gan trên mô bệnh học với hệ số tương quan Pearson $r=0,37(p<0,01)$. Nồng độ Fibrinogen và thời gian APTT không có tương quan với giai đoạn xơ hóa gan trên mô bệnh học $(p>0,05)$.

\section{BÀN LUẬN}

4.1. Số lượng hông câu và nồng độ hemoglobin. Qua nghiên cứu thây ở $\mathrm{BN}$ mắc BGDR số lượng hồng cầu trung bình là $4,28 \pm$ $0,68(2,34-5,80) \mathrm{T} / \mathrm{l} ;$ Có 45,0\% BN giảm SLHC $<4,2 \mathrm{~T} / \mathrm{l}$. Nồng độ $\mathrm{Hb}(\mathrm{g} / \mathrm{l})$ trung bình là 138,58 $\pm 19,18$ (84- 178) $\mathrm{g} / \mathrm{l}$; Có $16,7 \%$ BN giảm nồng độ $\mathrm{Hb}<120 \mathrm{~g} / \mathrm{l}$. Nồng độ $\mathrm{Hb}$ tương quan nghịch với giai đoạn xơ hóa gan trên mô bệnh học, với hệ số tương quan Pearson $r=-0,25$, sự khác biệt có ý nghĩa thống kê với $p<0,05$ (bảng 1 và bảng 3).

Kết quả này tương tự với nhận xét của một số nghiên cứu trong và ngoài nước ở $\mathrm{BN}$ mắc BGDR [1], [3], [2], [7]. Nghiên cứu của Huang và cs (2017) cho thây nồng độ $\mathrm{Hb}$ của nhóm

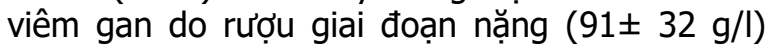
thấp hơn so với nhóm BN GNM $(154 \pm 16.75 \mathrm{~g} / \mathrm{l})$, viêm gan do rượu mức độ nhe $(146 \pm 30 \mathrm{~g} / \mathrm{l})$ và xơ gan do rượu $(113 \pm 32 \mathrm{~g} / \mathrm{l})$, sự khác biệt có ý nghĩa thống kê với $p<0,05$ [7]. Ở Việt Nam, Lê Thị Thu Hiền (2017) thấy BN mắc BGDR có SLHC trung bình là $3,61 \pm 0,89 \mathrm{~T} / \mathrm{l}$, nồng độ $\mathrm{Hb}$ trung bình là $113,46 \pm 30,09 \mathrm{~g} / \mathrm{L}$. Tỷ lệ BN giảm SLHC $<4,2 \mathrm{~T} / \mathrm{I}$ chiếm $69,9 \%$; tỷ lệ $\mathrm{BN}$ giảm nồng độ $\mathrm{Hb}$ $<120 \mathrm{~g} / \mathrm{l}$ chiếm 50,6\%[1]. Lê Quốc Tuấn (2019) thấy giảm SLHC là $66,3 \%$, giảm nồng độ $\mathrm{Hb}$ là 48,4\%[2]. Vũ Thị Thu Trang (2019) nghiên cứu ở bệnh nhân GNM thấy các xét nghiệm huyết học không biến đổi nhiều ở bệnh nhân GNM: chỉ có $11,8 \%$ BN giảm hemoglobin, $16,7 \%$ có giảm SLTC, $17,6 \%$ có tăng bach cầu, đặc biệt có $24,5 \%$ bệnh nhân có $M C V$ tăng. Hầu hết các trường hợp có tăng MCV đều là những đối tượng lạm dụng rượu [3].

4.2. Số lượng tiểu câu. Trong bệnh gan mạn tính, tiểu cầu thường giảm cả về số lượng và chất lượng do giảm sản xuất tiểu cầu trong tủy xương, cường lách, giảm sản xuất thrombopoietin và yếu tố tự miễn. Gia tăng phá hủy tiểu cầu còn do cơ chế miễn dịch do tăng số lượng tiểu cầu gắn IgG trong bệnh gan mạn tính. Trong BGDR, rượu ức chế tủy xương làm giảm sản xuất tiểu cầu và tác dụng trực tiếp trên lipid tiểu cầu [1], [2], [7].

Qua nghiên cứu thấy SLTC ở BN mắc BGDR trung bình là $179,79 \pm 78,90(37,50-413,00)$ G/l; có $35,0 \%$ BN giảm SLTC <140 G/l. SLTC tương quan nghịch với giai đoạn xơ hóa gan trên mô bệnh học, với hệ số tương quan Pearson $r=-$ 0,28 , sự khác biệt có ý nghĩa thống kê với $\mathrm{p}<0,05$ (bảng 1 và bảng 3 ). Số lượng tiểu câu trong nghiên cứu của chúng tôi cũng tương tự kết quả nghiên cứu của một số tác giả khác (bảng 5).

Bảng 5. Số lượng tiểu cầu ở bênh nhân mắc bệnh gan do rươu so với một số nghiên cứu.

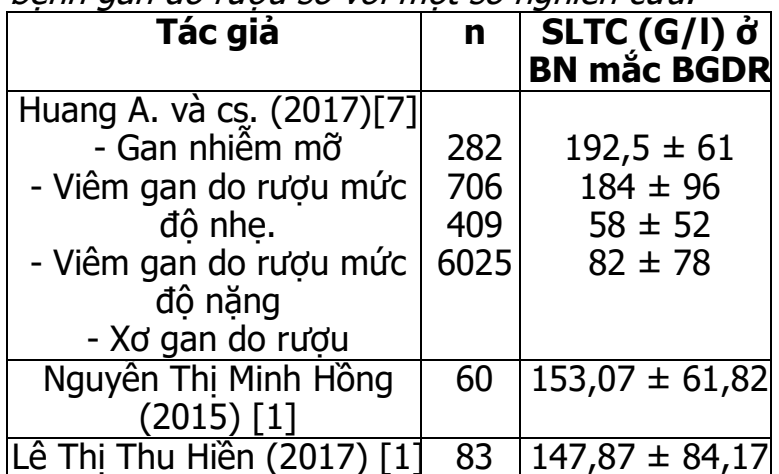

Nghiên cứu của Vijayakumar S. và cs. (2020) ở $119 \mathrm{BN}$ viêm gan do rượu (điểm MELD và Maddrey trung bình là $14,13 \pm 5,17$ và $36,45 \pm$ 29,63 ) thấy số lượng tiểu cầu, độ phân bố tiểu câu (PDW: platelet distribution width), thể tích trung bình của tiểu cầu (MPV: mean platelet volume) và độ nhớt của tiểu cầu (plateletcrit) lần lượt là 194,01 $\pm 178,82 \mathrm{G} / \mathrm{l}, 17,10 \pm 1,21,5,99$ $\pm 0,96$ và $0,14 \pm 0,04$. Độ phân bố tiểu câuu $(P D W)>18$ và thể tích trung bình của tiểu câuu (MPV) có tương quan thuận với điểm MELD. Diện 
tích dưới đường cong ROC cao nhất đối với độ nhớt của tiểu câuu (plateletcrit) là $0,622(p=0,7$; KTC $95 \%=0,500-0,743)$. Các chí số đánh giá tiểu cầu thay đổi đáng kể trong bệnh viêm gan do rượu, nhưng không dư đoán được mức đô viêm gan do rượu nặng có thể do các bệnh kết hợp như viêm tụy, xơ gan và nhiễm khuẩn [8]. Lề Quốc Tuấn (2019) nghiên cứu ở BN mắc BGDR thấy có $53,7 \%$ số BN giảm SLTC [2]. Lư Quốc Hùng (2018) nghiên cứu các $B N$ viêm gan B, C mạn tính thấy SLTC trung bình là 149,1 \pm 82,7 G/I [3]. Trần Thi Khánh Tường (2015) đánh giá tương quan giữa SLTC và giai đoạn xơ hóa gan thấy có mối liên quan nghịch chặt chẽ với hệ số tương quan Spearman $r=-0,39$ [6].

Như vây, giảm SLTC là một yếu tố dư đoán xơ hóa gan ở $\mathrm{BN}$ mắc bênh gan mạn tính nói chung và $B N$ mắc $B G D R$ nói riêng.

4.3. Một số chỉ số đông máu. Qua nghiên cứu ở BN mắc BGDR thấy tỷ lệ Prothrombin (\%) trung bình là $105,58 \pm 23,30 \%$ (từ $54,00 \%$ đến $164,95 \%)$; Có 6,7\% BN giảm tỷ lệ Prothrombin $<70 \%$. Tỷ lệ Prothrombin (\%) tương quan nghịch với giai đoạn xơ hóa gan với hệ số tương quan Pearson $r=-0,42(p<0,001)$. Chỉ số INR trung bình là $1,00 \pm 0,16$ (từ 0,45 đến 1,53 ); có $3,3 \%$ BN tăng chỉ số INR $>1,3$. Chỉ số INR tương quan thuận với giai đoạn xơ hóa gan với hệ số tương quan Pearson $r=0,37(p<0,01)$. Nồng độ Fibrinogen trung bình là $3,43 \pm 1,32 \mathrm{~g} / \mathrm{l}$ (từ 1,43 $\mathrm{g} / \mathrm{l}$ đến $7,32 \mathrm{~g} / \mathrm{l}$ ); Có $13,3 \%$ BN giảm nồng đô Fibrinogen $<2 \mathrm{~g} / \mathrm{l}$. Thời gian APTT trung bình là $28,28 \pm 4,57$ giây (14,40 giây- 40,30 giây); Có $1,7 \%$ BN thời gian APTT kéo dài $>40$ giây. Nồng độ Fibrinogen và thời gian APTT không có tương quan với giai đoạn xơ hóa $(p>0,05)$, (bảng 3.11 và bảng 3.26).

Nhận xét của chúng tôi cũng tương tự kết quả của một số nghiên cứu [3], [6], [8]. Vijayakumar S. và cs. (2020) cho rằng thời gian prothrombin kéo dài là những yếu tố dự báo có ý nghĩa cho bênh viêm gan do rượu [8]. Theo Trần Thị Khánh Tường (2015), chỉ số INR có tương quan thuận với giai đoạn xơ hóa gan: xơ hóa gan càng nặng chỉ số INR càng tăng [6]. Lư Quốc Hùng (2018) nghiên cứu các $B N$ viêm gan $\mathrm{B}, \mathrm{C}$ mạn tính thấy thời gian Prothrombin và chỉ số INR trung bình là 90,3 $\pm 11,2$ và $1,1 \pm 0,2$ [3].

Như vậy, gan có chức năng tổng hợp nhiều protein quan trọng trong quá trình đông máu, cầm máu và tiêu sợi huyết (những yếu tố đông máu: a1 antiplasmin, anti-thrombin, heparin cofactor II, kininogen trọng lượng phân tử cao, prekallikerin, protein), thời gian prothrombin
/IRN kéo dài có thể do chức năng tổng hợp các yếu tố đông máu bị suy giảm hoặc do thiếu vitamin $\mathrm{K}$ do suy chức năng gan. Do vậy, xét nghiệm chức năng đông cầm máu ở bênh nhân viêm gan mạn tính đóng vai trò rất quan trọng.

\section{KẾT LUẬN}

- Có 45,0\% số bệnh nhân mắc bệnh gan do rượu giảm số lượng hồng cầu $<4,2$ T/l; $16,7 \%$ bệnh nhân giảm nồng độ $\mathrm{Hb}<120 \mathrm{~g} / \mathrm{l}$ và $35,0 \%$ số bệnh nhân giảm số lượng <140 G/l. Nồng độ $\mathrm{Hb}$ và số lượng tiểu câu tương quan nghịch với giai đoạn xớ hóa gan trên mô bệnh học, với hệ số tương quan Pearson $(r=-0,25$ và $r=-0,28)$, sự khác biệt có ý nghĩa thống kê với $p<0,05$.

- Có 6,7\% bệnh nhân giảm tỷ lệ Prothrombin $<70 \%$; có $3,3 \%$ bệnh nhân tăng chỉ số INR $>1,3$. Có $13,3 \%$ bệnh nhân giảm nồng độ Fibrinogen $<2 \mathrm{~g} / \mathrm{l}$ và $1,7 \%$ bệnh nhân thời gian APTT kéo dài $>40$ giây. Tỷ lệ Prothrombin (\%) tương quan nghịch với giai đoạn xơ hóa gan trên mô bệnh học với hê số tương quan Pearson $r=$ $0,42(p<0,001)$. Chỉ số INR tương quan thuận với giai đoạn xơ hóa gan trên mô bệnh học với hệ số tương quan Pearson $r=0,37(p<0,01)$.

\section{TÀI LIẸU THAM KHẢO}

1. Nguyễn Thi Minh Hông, Nguyễn Nhược Kim (2015), "Đánh giá tác dụng của viên XG1 điều trì xơ gan do rượu giai đoạn Child - pugh B", Tạp ch Nghiên cứu Y hoc, 94 (2), tr. 110 - 118

2. Lể Thi Thu Hiển (2017), Nghiên cứu môt số đăc điểm lầm sàng, cận lâm sàng và chỉ số chống oxy hóa trong máu ở bệnh nhân mắc bệnh gan do rươu, Luân án Tiến sĩ y học, Đại học YD Thái Nguyên

3. Lư Quổc Hùng (2018), Nighiên cứu đặc điểm lâm sàng, cận lầm sàng và ý nghĩa của Fibroscan, Fibrotest trong chẩn đoán xớ hóa gan ở bệnh nhân viêm gan $B, C$ mạn tính, Luận án Tiến sĩ y học, Học viện Quân y

4. Vữ Thị Thu Trang (2019), Nghiên cứu đặc điểm lâm sàng, một số xét nghiệm, siêu âm và mô bệnh hoc bênh gan nhiếm mõ̃, Luận án Tiến sĩ y học, Viền NCKHYDLS 108

5. Lề Quốc Tuấn (2019), Nghiên cứu đặc điểm lâm sàng, cận lâm sàng và nồng độ một số cytokin huyêt tương trên bệnh nhân mắc bệnh gan man do rượu, Luận án Tiến sĩ y học, Đại học YD Thái Nguyên.

6. Trân Thị Khánh Tường (2015), Nghiên cứu giá trị chẩn đoán xơ hóa gan bằng phối hợp kỹ thuật ARFI với APRI ở các bệnh nhân viêm gan mạn, Luâan án Tiến sĩ y học, Đại học YD Huế.

7. Huang A., Chang B., Sun Y., et al (2017), "Disease spectrum of alcoholic liver disease in Beijing 302 Hospita I from 2002 to 2013", 96 (7), pp. 1-5.

8. Vijayakumar S., Viswanathan S., Jain D. (2020), "Utility of platelet indices in alcoholic hepatitis: a retrospective study", Porto Biomed J., 5(5): e082. 